\title{
BEDREIGING EN VERLOSSING \\ IN 2 KONINGS 6:24 - 7:20 - 'n LITERêR-TEORETIESE BENADERING
}

\author{
Gerrie Snyman \\ Departement Ou Testament \\ Universiteit van Suid-Afrika \\ PRETORIA
}

\begin{abstract}
Instead of regarding a biblical text as an archaeological field filled with revelations of God which only need to be exposed, this anicle focuses on the relationship between the tex and its readers. The aim is to discuss the way in which readers can be helped to interpret the text in a certain way. To read is an enjoyable experience which leaves no one untouched. In the play between intrigue and the development of various characters the readers are invited to get to know themselves. The text on which this approuch will be applied, is 2 Kings 6:24-7:20. This approach is part of a literay theoretical approach which is not always appreciated by Reformed scholars. Because of the novelty of this approach in the theology of the Gereformeerde Kerke in South Africa, this anticle endeavours to explain the legitimacy of the upproach. It also discusses the concept of narrator while illustrating the use of the concept in the above-mentioned text. The notion of perspective in the sense of focalisation and ideological perspective is also discussed.
\end{abstract}

\section{INLEIDING}

Die uitvinding van die boekdrukkuns, wat 'n groot stimulus vir die Reformasie was, het 'n onmiskenbare stempel op die Protestantse lyn van die Christelike godsdiens geplaas, deurdat die Bybel in die sentrum van die godsdiensbeoefening gekom het. Die boekdrukkuns het meer as ooit daartoe bygedra om die Christelike godsdiens saam met die Joodse godsdiens as boekgodsdienste kenbaar te maak. Juis omdat die Bybel as boek gelees word, is dit nodig om te kyk watter aspekte van boeklees oor die algemeen vrugbaar vir Bybellees aangewend kan word.

Die benadering waarvolgens daardie boeke wat handel oor die geskiedenis van Israel (die klassieke "historiese stof") as verteltekste gesien kan word, sluit aan by 'n aspek wat Helberg (1983:48) in sy openbaringshistoriese benadering erken as die lewendige en aanskoulike wyse waarop die geskiedenis van die Bybel weergegee word. Om "historiese stof" as verteltekste te benader, dui op 'n verfyning wat die algemene literatuurwetenskap meegebring het. Deur verteltekste as 'n leesbenadering te gebruik, kan die verhalende dele in terme van retoriek, toneelskikking, intrige en karakters ontleed word. 
Eerder as om die teks te beskou as 'n argeologiese veld vol Godsopenbaringe wat maar net blootgelê hoef te word, val die klem in hierdie artikel op die verhouding tussen die teks en die lesers ten einde te kyk hoe lesers in die leesproses gehelp kan word om 'n teks op ' $n$ bepaalde wyse te interpreteer. Om te lees is 'n genotvolle ervaring wat geen leser koud laat nie. In die spel van intrige en karakterontwikkeling leer die leser homself ken. Die teks waarop hierdie letterkundige benadering uitgetoets gaan word, is die beleg en die verlossing van Samaria in 2 Konings 6:24-7:20. Omdat die idee van Skrifgedeeltes as vertelling relatief nuut is in Gereformeerde geledere, word eerstens gepoog om die benadering se legitimiteit uit te spel. Daarna word die konsep van verteller en die soone vertellings bespreek waarna die soort vertelling waarmee lesers in 2 Konings 6:24-7:20 te doene het, onder die loep geneem word. Voortvloeiend uit die soort vertelling, sal die perspektief van die verteller vervolgens aan die orde kom. Ten slotte sal gelet word op die waarde van so 'n analise.

\section{I.EGITIMITEI'I" VAN 'N LITERêR-TEORETIESE BENADERING}

Die sentraliteit van die Bybel het 'n sterk invloed uitgeoefen op die literatuurwetenskap. "Sekulêre" literatuur het vele leidrade bekom op grond van verskeie Bybelleesmodelle deur die eeue heen. Gadamer (1986:177-269) beskryf juis die geskiedenis van die hermeneutiese probleem sedert Schleiermacher op grond van wat in die teologie gedoen is. As gevolg van 'n sekularisasieproses is hierdie situasie omgekeer, sodat die naelstring tussen teologie en literatuur wetenskap uiteindelik aan die begin van die twintigste eeu deurgeknip is. Sedertdien het die literatuurwetenskap in geheel selfstandig geword en het dit, soos aangedui deur Wunberg (1983:202), 'n eie paadjie geloop.

Waar die teologie vroeër 'n invloed kon uitoefen op hermeneutiese vrae van die literatuur in die algemeen, het die literatuurwetenskap, met die nuwe perspektiewe wat sedert D.F. StrauB verkry is, daardie rol begin oorneem, sodat die teologie vandag in 'n groot mate van onder andere die literatuurwetenskap afhanklik geword het. Literatore hou hulle ook inderdaad besig met die lees van die Bybel met behulp van een of ander literêr-teoretiese benadering, byvoorbeeld Gräbe (1986a; 1986b; 1990) en Jauß (1987). Teoloë het ook nie agterweë gebly nie, byvoorbeeld Vorster (1977), Van Aarde (1982), Deist (1986) en Potgieter (1990).

Tog is die gebruik van 'n literêr-teoretiese benadering as ' $n$ middel om die Bybel te lees, aanvanklik nie baie goed in sommige Gereformeerde kringe ontvang nie. In 1977 het W.S. Vorster ('n Nuwe-Testamentikus) by sy intreerede aan Unisa onder meer voorspraak gemaak vir 'n literêr-teoretiese benadering op grond van die teorie van die Duitse letterkundige Johannes Anderregg. J.C. Coetzee (1979), professor in die Nuwe 
Testament van die Teologiese Fakulteit aan die PU vir CHO, het ernstige voorbehoude oor hierdie benadering uitgespreek. Hy het hierin veral 'n verskil in Skrifbeskouing gelees. Volgens hom sou daar te veel klem geplaas word op die menslike arbeid verbonde aan die teboekstelling van die Bybel ten koste van - soos hy dit stel- God wat Homself in die Bybel openbaar.

Aan die een kant lyk dit of Coetzee se afwysing gebore is uit 'n vrees vir die indra van 'n vreemde Skrifbeskouing in die openbaringshistoriese benadering. Aan die ander kant moet 'n mens ook in gedagte hou dat die Gereformeerde teoloë met Vorster se intreerede die eerste keer regstreeks met 'n literêr-teoretiese benadering gekonfronteer is. Coetzee se reaksie is 'n naturrlike reaksie om dit wat vreemd is en waarvan mens geen kennis dra nie, af te wys. Mens kry byna die indruk van bedreigdheid. Sy kollega en naamgenoot, P.J. Coetzee, wat op daardie tydstip rektor van Teologiese Skool op Potchefstroom was, verwoord hierdie gevoel met die viering van die honderd-en-tiende verjaarsdag van die Teologiese Skool, wanneer hy (1979:7) in die Goue Kandelaar skryf dat die "suiwer Skriftuurlike gereformeerde teologie" besig is om 'n al hoe eensamer paadjie te loop omdat teologie deur mensgesentreerdheid, sekularisme en horisontalisme besmet word. .

Wantroue teenoor literêr-teoretiese metodes word in sommige kringe geskep omdat geglo word dat die uniekheid van die Bybel nie deur so 'n metode tot sy reg kom nie (cf Kugel, 1981:234). Die uniekheid van die Bybel word deur Coetzee (1984:19) gedefinieer as verbale kommunikasie van God tot sy volk. Vir Kugel en Coetzee gaan dit om 'n bepaalde siening van die oorsprong van die Bybel: die Bybel kom van God af en getuig van en oor God se werk in die geskiedenis. Omdat die Bybel 'n weergawe van feite oor en van God is, is dit geregtig op besondere behandeling, iets waaraan die openbaringshistoriese benadering klaarblyklik voldoen.

Die openbaringshistoriese benadering steun baie sterk op Calvyn se hermeneutiek (kyk veral Floor, 1970 en 1980), soos verfyn deur Greijdanus (1946:183 e.v.). Uit Greijdanus se hantering van Calvyn, en uit Kraus (1977:8-18) se opsomming van Calvyn se hermeneutiek kom dit voor asof Calvyn, wat onder die invloed van die Renaissance gestaan het, aanvanklik baie gaan leen het by sy tyd se hantering van antieke tekste. Calvyn se leeswyse van Augustinus toon byvoorbeeld merkbare ooreenkomste met sy hantering van die Bybel (vgl. Smits, 1957:249-253). Calvyn het eenvoudig 'n letterkundige of literatuurteoretiese benadering wat in daardie tyd geldig was, nagevolg.

Coetzee (1984:18) trek 'n duidelike verband tussen die uniekheid van die Bybel en inspirasie. Inspirasie deur die Heilige Gees maak die Bybel enig in sy soort. Met ander woorde, inspirasie is die enigste punt van verskil tussen sekulêre literatuur en die 
Bybel. Die vraag is egter hoe die idee van inspirasie die fisiese lees van die Bybel deur enige leser beïnvloed. Die gebruik van 'n literêr-teoretiese benadering beteken nie om summier die rol van die Heilige Gees in die teboekstelling van die Bybel te ontken nie. Dit beteken alleen dat daar gefokus word op die menslike aspek van die lees van 'n gedeelte, want vir sover as wat die menslike oog kan sien, geskied sekulêre literêre kommunikasie op dieselfde wyse as religieuse literêre kommunikasie.

So 'n gelykstelling impliseer nie 'n ontkenning van die werk van die Heilige Gees nie. Dit beteken ook nie om die Heilige Gees in hakies te plaas nie, soos Schulze (1988:151) meen die gevolg van die gebruik van literêre teorieë in die eksegese van die Bybel is nie. God kan nie gekontroleer word nie maar die mens wel, veral as daardie mens die Bybel "wetenskaplik" wil lees. Die «nigste manier waarop so iemand, byvoorbeeld 'n eksegeet, sy lesing van 'n teks kan kontroleer, is om bewustelik te lees. Geen leesproses geskied sonder dat die lesers eers vrae aan die teks stel nie. Die tipe vrae wat gevra word, bepaal wat die soort antwoord is wat lesers gaan kry. Gevolglik moet die vrae wat lesers aan die teks stel, duidelik verdiskonteer word. Die gebruik van 'n literêr-teoretiese metode is 'n poging om van daardie vrae op 'n wetenskaplike wyse te verantwoord sodat die uiteindelike resultaat van die leesproses ook op wetenskaplikheid aanspraak kan naak.

Die verskil in kommunikasie tussen 'n religieuse : ks soos die Bybel en enige ander sekulêre literatuur moenie in die teks gesoek word n e, maar eerder in die gemeenskap waarbinne die teks funksioneer. Die lees van die Bybel en 'n roman is dieselfde in dié sin dat 'n proses voltrek word waar ligstrale opgevang word deur die retinas van die lesers se oë, waar senuwee-impulse na die lesers se brein oorgedra word, die gedrukte materiaal herken en georganiseer word terwyl oordrag plaasvind en assosiasies gemaak word in terme van die lesers se vermoë en vorige envarings. Die Bybelteks, soos enige ander teks, bevat nie 'n geslote werklikheid of 'n betekenis wat deur 'n otteur vir eens en vir altyd daarin gesit is nie. Tog moet erken word dat in 'n ander sin die leesproses (van die Bybel) van ander tekste variëer, naamlik met betrekking tot die manier waarop 'n teks deur lesers verstaan word. Indien lesers byvoorbeeld die Bybel as 'n besondere boek reken deur dit te assosieer met metafisiese taal en transendensie, dan getuig hierdie houding ten opsigte van die teks van 'n bepaalde soort assosiasie. Tekste wat hiermee verband hou, word met religie geassosieer en hulle word as religieuse tekste beskou. Deur die Bybel as 'n religieuse teks te beskou, word dit as boek nog lewend gehou. Die lesers laat die teks herleef elke keer wanneer hulle lees en 'n nuwe betekenis daaraan heg. Hoewel Augustinus en die Bybel as antieke tekste "dieselfde" gelees word, is daar wel 'n verskil omdat die Bybel deur die gemeenskap anders ervaar word as Augustinus se geskrifte. Beide is religieuse tekste, maar dit is net die Bybel waaraan die gemeenskap die metafoor van goddelike spreke heg. Om aan die Bybel uniekheid toe te dig, is 'n manier van 'n bepaalde gemeenskap om die boek met gesag 
vir hulle betrokke gemeenskap te beklee.

In Gereformeerde kringe het hierdie metafoor van goddelike spreke en die uniekheid van die Bybel uitgekristalliseer in die gedagte van openharingsgeskiedenis. As doelbewuste Calvinistiese leeswyse konsentreer hierdie benadering op die gebeure wat in die teks beskryf staan. Hierdie gebeure, wat oor God iets sê, staan in die geskiedenis wat, so word geglo - deur God beheer word. Die einddoel is om alles na God terug te voer. Hieragter skuil 'n didaktiese doel: die leser moet 'n bepaalde siening oor God geleer word. Die Bybelteks dien as 'n deposito van Godsopenbaring wat deur die lesers ontgin moet word. In die proses bly die artistieke element van die teks en die leser se genot van die teksspel dikwels agterweë, want die Bybelteks word eenvoudig gelees asof dit een of ander wetskode is warvan beginsels alleen gepositiveer hoef te word. Die verhaalaspek, naamlik die karakters, hulle onderlinge verhouding en ontwikkeling en die estetiese aspek, naamlik die manier waarop die gebeure in bepaalde opeenvolging gerangskik, asook aanskoulik aangebied word, is elemente wat help om die verhaal te verstaan, en daar kan nie summier gesoek word na dit wat "oor", "van" en "deur" God gesê word nie.

\section{DIE KONSEP VAN VERTELLER EN VERTELLING}

Berlin (1983:17) meen om deur die benadering van tekste as verteltekste tot ' $n$ beter begrip van 'n teks te kom. Sy meen dat indien 'n mens weet hoe 'n teks betekenis genereer, ' $n$ mens die teks beter kan verstaan. Enige teks wil verstaan word. Tog vind verstaan nie plaas in 'n vakuum nie. 'n Leser moet bepaalde strategieë aanwend ten einde by ' $n$ bepaalde verstaan uit te kom. Een sodanige strategie is die konsep van vertelling waar ' $n$ verteller 'n verhaal vertel vanuit 'n bepaalde perspektief. Deist (1986:88) en Berlin (1983:44) vergelyk die idee van perspektief of gesigshoek met ' $n$ rolprent teenoor 'n teaterstuk of toneel soos dit in die werklikheid voor 'n kameralens afspeel. In 'n toneelstuk sien die gehoor alles net vanuit een perspektief. Die gehoor is alleenlik in staat om op die verhoog te fokus en hulle kan nie hulle sitplekke verlaat nie. In 'n rol- of televisieprent word die verhaal egter deur die lens van die kamera gesien. Daar is nabyskote wat 'n bepaalde faset van die toneel afneem en verafskote wat die toneel in sy geheel afneem.

Volgens hierdie benadering word die kyker se perspektief bepaal en beheer deur die kankera: die waarnemers kan net sien wat die kamera hulle laat sien. Die kameralens fokus alleen op bepaalde elemente wat gesien word. Die verteller vertel uiteindelik wat gesien word, maar die lens laat net bepaalde inligting deur, sodat die lesers die gebeure van die verhaal alleenlik deur die lens waarneem. As die kameralens net op een persoon fokus, kan die kyker nie agterkom wat die ander persone doen nie. 
In hierdie verband moet daar onderskei word tussen die vertelhandeling en dit wat gesien word. Bal (1985:108) verduidelik die verhouding tussen die twee elemente met die term fokalisasie wat sy verkies bo die term perspektief. Volgens haar onderskei laasgenoemde begrip nie tussen vertelhandeling en waarneming nie, want beide handelinge word as een handeling geag. Bal baseer hierdie onderskeid op Genette se gebruik van die begrip fokalisasie (vgl. Genette 1988:64-66). Volgens Genette (1980: 189-194) kan hierdie fokalisasie gefikseerd of gevariẻerd wees. Dit is gefikseerd wanneer die gebeure net deur die oë van een karakter waargeneem word. Wanneer die gebeure deur verskeie karakters waargeneem word, is die fokalisasie gevariëerd. Rimmon-Kenan (1983:43) sien fokalisasie as die gesigshoek waarmee die verhaal in die teks gegiet word en deur 'n verteller verbaal geformuleer word. Genette (1988:74) sien fokalisasie as "situated focus", met ander woorde 'n filter wat alleen daardie inligting deurlaat wat deur die situasie vereis word.

Die verteller moet gesien word as 'n abstrakte konstruksie van wie die lesers nie antwoorde op hulle vrae kan verwag nie. Die verteller is 'n literêre instrument wat aangewend word om die gebeure van die verhaal voor die geestesoog van die lesers te laat afspeel sonder om aan die lesers te sê presies hoe die verhaal geïnterpreteer moet word. Die lesers word wel deur die verteller met verskillende momente van een gebeurtenis gebombardeer, maar daardie momente word nie rond en bont gegee nie. Hulle is op ' $n$ bepaalde wyse gestruktureer. Wanneer die leser opmerk hoe die momente deur die verteller aanmekaar gesit word, word sy interpretasie wel in 'n bepaalde rigting gestuur. Hoewel die verteller die leser deur die verhaal begelei, hang die uiteindelike interpretasie wat met die waarneming gepaard gaan, af van die leser se eie ervaring.

\section{2 KONINGS 6:24-7:20 AS TONEELMATIGE VERTELLING}

Die vertelling van die beleg en verlossing van Samaria kan as toneelmatig gekarakteriseer word. In so 'n vertelling word die handeling in verskillende opeenvolgende tonele opgebreek, terwyl elke toneel gebeure op 'n bepaalde plek en op 'n bepaalde tydstip voorstel (cf Licht, 1978:29-30). Die aandag word gevestig op dade en woorde van karakters. Die toneelmatige vertelling is nie die enigste soort vertelling nie. Daar is ook die eenvoudige vertelling en die beskrywing. So kan daar tussen die verskillende tonele van die toneelmatige vertelling eenvoudige vertellings wees om verwarring te vermy en om afwisseling aan die aanbieding te verskaf. In 'n eenvoudige vertelling word 'n reeks gebeure net in die allernoodsaaklikste besonderhede weergegee. Detail word vermy en die verhaal word so glad as moontlik vertel. Wanneer dit nodig is om in die vertelling persone, plekke en voorwerpe te beskryf in terme van hoe hulle lyk, ruik, dink en doen, het mens met 'n beskrywing te doen. Volgens Berlin (1983:46) is die toneelmatige vertelling egter die een wat die meeste in die Ou Testament voor- 
kom. Die ander vertelwyses, soos kommentaar, eenvoudige vertelling en beskrywing staan aan die toneelmatige vertelling ondergeskik. Gräbe (1986a:165) is byvoorbeeld van mening dat die evangelies uitstekende voorbeelde van toneelmatige vertellings in die Nuwe Testament is.

Kom ons kyk na die beleg van Samaria as 'n toneelmatige vertelling.

* 6:24-25: algemene situasietekening

Aan die begin van die verhaal word aan die lesers, deur middel van 'n agtergrondskoot, ' $n$ algemene situasietekening aangebied by wyse van 'n eenvoudige vertelling wat dien as openingstoneel vir die verhaal wat gaan volg. Op 'n baie eenvoudige en direkte wyse neem die lesers kennis van dit waaroor die verhaal gaan, naamlik'n beleg. Die lesers word bewus van wie die belangegroepe is, naamlik Israel en Aram en vind ook uit wat die gevolg van hierdie beleëring is, naamlik hongersnood. Sonder onnodige detail kry die lesers 'n panoramiese blik op die gebeure rondom Samaria en weet hulle waaroor die verhaal gaan handel.

* 6:26-31: eerste toneel - koning en vrou

Vanuit die agtergrondoorsig word daar nou 'n nabyskoot gegee van 'n spesifieke situasie. Die lesers kry 'n blik op die koning wat op die stadsmuur staan. Die insetsel het ten doel om die gevolge van die hongersnood waarvan in die algemene situasietekening melding gemaak is, te illustreer. Dit is nie snaaks om die koning op die stadsmuur te vind nie, want hy moes as heerser en bevelvoerder die situasie van die beleg dophou. Die oudiënsie tussen hom en die vrou openbaar die mate waarin die inwoners van die stad geraak is, naamlik dat hulle selfs in staat was om oor te gaan tot kannibalisme. Ná hierdie oudiënsie vind die lesers 'n nabyskoot van die koning wat homself in ' $n$ bepaalde toestand vertoon; naamlik een van roubeklag en wraak. Sy rou kan gesien word in die roukleed wat hy onder sy klere dra en sy wraakgedagtes kom na vore in die eedswering waarvolgens hy Elisa wou laat doodmaak omdat hy hom verantwoordelik hou vir die benarde situasie van die stad en sy inwoners. Op hierdie wyse word Elisa by die konflik ingesleep. Die verwysing na Elisa berei die grond voor vir die komende konflik tussen hom en die koning. Dit maak hierdie toneel funksioneel.

\section{* 6:32-7:2: Elisa is in die stad van Samaria}

Die koning se wraakswering vestig die aandag op Elisa, op wie die toneel vervolgens fokus. Die lesers neem kennis dat Elisa in die stad is 
en inderwaarheid saam met die res van die inwoners ly. Voorts neem hulle kennis van iets van die binnekring van die stadslewe, naamlik die oudstes wat by Elisa vergader. Elisa word van nader geskets deurdat die lesers kennis neem van besondere gawes wat hy het, soos om die koning se gedagtes te lees. Die fokus op Elisa toon dat die koning nog nie daarin geslaag het om sy plan uit te voer nie. Die koning se boodskapper word effektief uitgesluit en die konflik wat in die vorige toneel gesuggereer word, vind plaas. Die fokus val op die profesieë en die ongeloof van die adjudant. Die koning en Elisa word aan die einde van die toneel op die agtergrond geskuif. Die tafel is gedek vir die kragmeting tussen die koning en Elisa. Die lesers sit met die volgende vraag: hoe gaan hierdie profesieë bewaarheid word? Gaan die adjudant hom op die ou end bekeer?

- 7:3-9: die poort waardeur die verlossing sighaar moet word

In die volgende toneel word die lesers se aandag gevestig op die poort van die stad Samaria. Dit is die plek waar die gevolge van 'n wonderbare verlossing hulleself moet manifesteer. Nuwe karakters word nou ingevoer in die gedaante van melaatses wat die taak kry om die verlossing te gaan ontdek. In verse $3-4$ neem die lesers kennis van die innerlike gesteldheid van die melaatses en hulle penarie. Die verteller wys op vernuftige wyse hoe hulle plannetjies in diens staan om die profesieë van Elisa te gaan vervul. In verse 5-8 word die lesers met 'n beskrywende vertelling gekonfronteer. In byna poëtiese terme word beskryf wat die melaatses by die laer gevind en gedoen het. So half terloops, in parentese, word die lesers in kennis gestel hoekom alles verlate is by die Aramese laer. Die gevoel van die melaatses word ook deurgegee by wyse van hulle onderlinge raadpleging. Hulle kom onseker voor, voel skuldig en probeer mekaar moed inpraat.

\section{- 7:10-11: die ontknoping word vertraag}

$\mathrm{Na}$ die melaatses van die Aramese leër teruggekeer het, vind die lesers hulle weer by die poort waar hulle aan die poortwagters rapporteer wat hulle gesien het. Die ontknoping van die verhaal word nou vertraag deurdat die melaatses nie regstreeks voor die koning kan verskyn nie.

- 7:12-13: die koning neem uiteindelik kennis

Die poortwagters neem nou die boodskap verder tot by die paleis van die koning. Hier is beweging van die buitenste deel van die stad tot by die binnelewe, soos toe die blik vroeër in die verhaal verskuif het van 
die koning op die muur na Elisa se huis in die binnestad. Die koning kom wantrouig voor, want indien die profesie bewaarheid gaan word, moet hy Elisa daarvoor erkenning gee. Daar word net soos by die melaatses met mekaar gekonfereer voordat daar tot 'n besluit gekom word.

* 7:14-15: die melaatses getoets

Die melaatses se berig word nou met die daad getoets deurdat 'n verkenningstog uitgestuur word. Die lesers word nou vinnig heen en weer tussen die stad en die laer gelei.

* 7:16-20: die ontknoping van die verhaal

Nadat die melaatses se berig aanvaar is, kan die verhaal ontknoop word. Daar word gewys op die vervulling van die twee profesieë, een met betrekking tot die volk en die ander met betrekking tot die adjudant. Die verhaal is eers klaar wanneer die profesie met betrekking tot die adjudant in vervulling gaan. Verse $16-20$ is eweneens kommentaar op die gebeure. Nadat die hele gebeurlikheid in oënskou geneem is, kan gesê word dat dit gebeur het volgens die woord van die profeet. In die kommentaar word 'n vroeëre gebeurtenis in herinnering geroep terwyl die fokus skerp op die ongeloof van die adjudant en sy gevolglike dood val.

Uit die voorafgaande beskrywing van hoe die vertelling oor die beleg en verlossing van Samaria daar uitsien, val sekere riglyne op wat die lesers se interpretasie van die storie in 'n sekere rigting moet stuur. Buiten die kommentaar aan die einde van die verhaal, teken die verteller sekere karakters positief en ander negatief. Die koning op die muur dui daarop dat die koning as krygsbevelvoerder net sy taak kom uitvoer het om die troepe op die muur te inspekteer. Sy vermeende militêre bevoegdheid word egter gekontrasteer met sy onvermoë om die vrou op die muur te help. Die lesers dink onwillekeurig aan Salomo wat ook in so 'n situasie verkeer het (1 Konings 3:16-28). Met sy wysheid kon hy die situasie beredder, maar hierdie koning het nie daardie soort wysheid nie. Elisa tree op as 'n konvensionele profeet. Ily doen wonders, hy word altyd in sy huis gevind in die Aramese verhale $(5: 9 ; 6: 32)$. Hy word besoek deur konings (3:12;6:32). Sy profesie word gewoonlik binne vieren-twintig uur vervul $(3: 20 ; 7: 1)$. Die adjudant is die eintlike antagonis in die verhaal omdat hy die profeet se sending probeer dwarsboom. Sy gebrek aan geloof lei tot sy ondergang.

Die ander karakters in die verhaal tree op as agente of helpers. Die vrou op die 
muur is die spreekwoordelike vuurhoutjie in die kruitvat. Met haar bekentenis met betrekking tot kannibalisme, word nog meer ellende by al die ander probleme wat die beleg van die stad meegebring het, bygevoeg. Die koning staan nie alleen magteloos daarteenoor nie, maar ook sprakeloos. Hy kan niks sê nie, maar skeur eerder sy klere as teken van die ellende waarin die stad hom bevind. As hy wel praat, is dit nie oor sy afkeer van kannibalisme nie, maar sy frustrasie en woede oor die situasie van die hele stad.

Wat die oudstes van die stad presies by Elisa kom soek het, weet die lesers nie. Wat wel moontlik is, is dat hulle die beleg as 'n godsdienstige aangeleentheid beskou het en dat hulle deur die profeet Elisa hulp van die Here wou bekom het. Hulle funksioneer as getuies ten opsigte van die woord van die Here wat deur die profeet gespreek word. As die woord nie vervul word nie, sal Elisa 'n leuenprofeet wees. Word die woord wel vervul, sal hulle die profeet se gesag moes bevestig. Hulle is getuies van die konflik tussen mens en God: die koning wil nie langer op uitkoms wag nie en wil self die toestand beredder. Hierteenoor kom God met 'n belofte dat die toestand binne vier-en-twintig uur sal verander.

Die melaatses dien alleen om die verlossing aan die koning en die volk bekend te maak. By hulle vind mens situasionele ironie. Rhoads en Michie (1982:60) sê so 'n ironie kom voor wanneer daar 'n verskil is tussen wat 'n karakter verwag sal gebeur en wat in werklikheid gebeur. As melaatses is hulle die verworpenes van die samelewing. Hulle is volgens wet uit die stad verban en daarom vind die lesers hulle by die poort. Tussen die poort en die Aramese laer is 'n stuk niemandsland: geen Israeliet kan dit daar waag sonder die gevaar om doodgemaak te word nie. Dit plaas die melaatses in 'n dilemma: hulle is tussen twee magte vasgevang. Vanweë hulle siekte mag hulle nie in die stad gaan kos soek nie en vanweë die beleg kan hulle ook nie buite die stad gaan kos soek nie. Hulle word voor 'n keuse geplaas van 'n gewisse dood (as hulle bly waar hulle is) en 'n moontlike dood (as hulle by die Aramese laer gaan kos soek). Die ironie is dat hulle nie die dood tegemoet gaan nie, maar eerder lewe in oorvloed kry. Hierdie mense wat ongeskik was vir militêre diens en wat eintlik uit Samaria gedros het, vind dat die beleg gestaak is omdat die Aramese leër self gedros het.

\section{DIE VERTELLER EN SY PERSPEKTIEF}

\subsection{Fokalisasie}

Normaalweg word daar tussen twee soorte vertellers, naamlik 'n eerstepersoonsverteller en 'n derdepersoonsverteller onderskei (cf Deist 1986:72). Die eerstepersoonsver- 
teller bied sy verhaal aan as 'n outobiografie maar die derdepersoonsverteller skep ' $n$ afstand tussen hom en die verhaal. Hierdie soort verteller laat die indruk dat hy of sy nie direk betrokke is by die verhaal nie. Die afstand gee aan die verteller ' $n$ kenmerk van alwetendheid. Die verteller is bekend met die karakters se gevoelens, hy dra kennis van die verlede, hede en toekoms, hy vergesel die karakters tot waar hulle veronderstel is om alleen te wees. Die verteller het kennis oor wat tegelykertyd op verskillende plekke gebeur. Genette (1988:74) meen egter dat dit nie soseer om "alomteenwoordigheid" gaan nie as om die volledigheid van inligting, wat die lesers, wanneer die inligting aan hulle verskaf word, "alomteenwoordig" maak.

Genette noem egter ook 'n ander onderskeid tussen die vertellers. Hy (1988:74-75) gooi dit oor die boeg van fokalisasie: wanneer die fokus met die karakter saamval, sodat die verhaal die innerlike van 'n karakter vertel, dan het mens te doen met interne fokalisasie. Daarteenoor staan eksterne fokalisasie: die fokus van die verhaal staan buite die karakters, sodat die leser geensins iets van die karakters se eie gedagtes kan verneem nie. Dit lyk of interne fokalisasie by albei vertellers kan voorkom, maar eksterne fokalisasie kan alleen by die derdepersoonsverteller voorkom, veral wanneer hierdie verteller nie een van die karakters is nie.

Die beleg en verlossing van Samaria word nie deur een van die karakters vertel nie. Die verteller staan buite die verhaal. Die fokalisasie is gevariëerd, want die verteller verskuif die fokus telkens van een karakter na 'n volgende:

* Hy neem waar wanneer die koning met een van sy vroulike onderdane 'n gesprek voer oor die benarde situasie waarin die volk verkeer (6:26-28).

* Hy hoor dat die koning wraak gesweer het (6:30-31).

- Die verteller is skielik in die huis van Elisa saam met die oudstes (6:32-7:2).

- Ily dra kennis van die binnekring van die melaatses by die stadspoort (7:3-5).

- Die derdepersoonsverteller is boonop ook in die Aramese laer wanneer hulle die plek oritruim (7:6-7).

* Hy is ook in die koning se paleis waar besluit moet word of die Arameèrs agtervolg moet word of nie (7:12-13).

* Die verteller is ten slotte ook in die poort wanneer die adjudant doodgetrap word (7:17-20).

Omdat die verteller wegstaan van die gebeure in die verhaal, kan hy net die verhaal vertel deur middel van die verskillende karakters. Hierdeur staan die verteller sy primêre posisie as verieller af aan sekondêre woordvoerders (vgl. Gräbe 1986a:167 en 1986b:276), deurdat hy die verhaal oorlaat aan die akteurs wat optree binne die wêreld wat die verteller skep. Tog bly die verteller die fokalisator omdat hy die instansie is wat die verskillende elemente van die storie waarneem. Aan die einde van die verhaal 
lewer hy kommentaar op die gebeure, soos dit blyk in 7:16-20. Met hierdie kommentaar dring hy, as primere woordvoerder, sy siening op aan die leser, deurdat hy die gebeure as die vervulling van twee profesieë sien.

Hierdie tipe opdringerige kommentaar word nie volop in die verteltekste in die Ou Testament gevind nie. Licht (1978:31) meen dat kommentaar meesal voorkom in byvoeglike naamwoorde en sydelingse opmerkings. Dit is volgens hom die verteller se ekwivalent vir 'n verhoog se rekwisiete waardeur lesers verplig word om dinge te veronderstel eerder as om dit op 'n skinkbord vir die lesers te gee om presies te sien. Met hierdie kommentaar kom die leser agter met watter gesigspunt die verteller die gebeure benader het. Daardie gesigspunt blyk op die ou end ook dié van die protagonis, Elisa, te wees.

lemand wat vertel, is iemand wat kan sien. Rimmon-Kenan (1983:72) sè dit is onmoontlik vir iemand om te vertel sonder om iets van sy siening of gesigspunt te verraai. Dit is met hierdie gesigspunt waarmee perspektief te make het. Die gesigspunt waarmee, of van waaruit, 'n hele verhaal vertel word, staan as die ideologiese perspektief bekend. Dit is nie net wie vertel en wat gesien word wat belangrik is nie, maar ook hoe gesien word. Van Aarde (1982:60) meen dat dit die gesigshoek is van waaruit die verteller die wêreld wat in die vertelling geskep word, beoordeel. As mens Bal en Genette se besware oor die begrip perspektief in ag moet neem, dan val die benaming ideologiese perspektief dalk swaar op die oor. Maar die onderskeid tussen fokalisator en verteller is dat die verteller vertel wat andere (of hyself) gesien het. In die verteldaad le interpretasie opgesluit, wat dalk beter deur die begrip ideologiese perspektief verwoord word. Maar waaruit bestaan die verteller van die verhaal van die beleg en verlossing van Samaria se "ideologiese perspektief"? Sy perspektief op die koning en Elisa gee aan die leser 'n aanduiding van die hoek waarmee hy die gebeure benader.

\subsection{Die perspektief op die koning en Elisa}

Die tweede toneel van die verhaal (6:26-31) vertel van 'n gesprek tussen die koning van Israel en 'n vrou. Die koning word simpatiek benader deurdat hy geteken word met 'n roukleed aan, wat eers sigbaar word nadat hy sy klere geskeur het as teken van ontsteltenis toe hy van die kannibalisme onder sy volk verneem het. Die roukleed wat gemaak is van sak waarin graan gebère word (vgl. Gen. 42:25) het groot simboliese waarde. Dit is veral gedra in tye van swaarkry en berou. In die verhaal van Jona word die koning van Ninevé geteken as een wat 'n roukleed aan het, selfs saam met die diere, as teken van hulle berou oor sonde (Jona 3:8). As Jakob hoor van Josef se vermeende dood, skeur hy ook sy klere en hy trek 'n roukleed aan (Gen. 37:34). Met die dood van Abner beveel Dawid sy manskappe om hulle klere te skeur en 'n rou- 
kleed aan te trek (2 Sam. 3:31). Hiskia skeur sy klere en trek 'n roukleed aan wanneer hy Sanherib se eis om oorgawe hoor (Jes. 37:1). Wanneer die koning in die verhaal oor die beleg van Samaria met 'n roukleed op die muur verskyn, wys die verteller dat die koning nie afsydig staan teenoor die katastrofe nie. Hy ly saam met die volk en hy wys dit sigbaar deur middel van 'n roukleed, so asof hy God se genade wil afsmeek om hulle nie in die hande van die Arameërs te laat val nie. Soos in die geval van Ninevé, dien die roukleed van die koning as sigbare simbool van die smart en die lyding van die hele volk (Gray, 1970:523).

Sodra die naam van Elisa die eerste keer in die verhaal genoem word - wanneer die koning wrakk sweer - verander die positiewe houding teenoor die koning in 'n negatiewe een. Om die een of ander rede sit die koning sy medelyde met die smart van die volk om in woede jeens Elisa, wie se verhouding met die koning van Israel nooit na wense was nie. In 2 Konings 3:14 sê Elisa dat hy geen agting het vir enigeen wat uit die huis van Agab kom nie. Hy help die koning alleen vanwee sy agting vir die koning van Juda. Die rede waarom die koning vir Elisa kwaad is, is nie so belangrik nic. Wat meer belangrik is, is dat die spaming tussen hulle deel vorm van die patroon wat in die verhale van Elisa gevolg word. Hierdie spanning is te wyte aan die twee sienings wat hulle onderskeidelik verteenwoordig:

* Die koning van Israel, die bevorderaar van die Baälgodsdiens en vooruitgang in 'n nuwe bedeling (cf Eichrodt 1983:326).

* Die man van God, die profeet Elisa, wat stry vir diens aan Jahwe en 'n leefwyse wat daarmee gepaardyatan (Von Rad 1982:26).

Profete soos Elisa en Elia het deur hulle optrede probeer wys dat daar iets beters was as aardse vooruitgang en vermeerdering van wêreldsgoed, iets wat veral gedurende die dinastie van die Omriedehuis posgevat het. Hierdie materialisme is byvoorbeeld duidelik vergestalt in besonder mooi geboue soos die ivoorpaleis van Agab (1 Kon. 22:39), 'n toring en 'n voorraadskuur (1 Kon. 22:33-38). Daar was ook 'n luukse lewenstyl wat alleen vir 'n groepie mense beskore was terwyl 'n gewone mens soos Nabot aan hulle uitgelewer was. Dieselfde het skynbaar gebeur met die eiendom van die Sunemmitiese vrou wat Samaria vanweë hongersnood verlaat het (2 Kon. 8:1-6). Die arm man het swaar finansiële laste gedra, soos die weduwee wie se twee kinders deur haar skuldeiser as slawe opgeëis is ( $2 \mathrm{Kon} .4: 1$ ). Met die beleg van Samaria is die stad hierdie rykmanslewe ontneem. Hulle moes hulleself verlaat op eselskoppe, duiwemis en, les bes, kannibalisme. Die koning is sy voorspoed ontneem en daarvoor het Elisa die skuld gekry.

Die koning word dus deur die kring van Elisa beskou as 'n opstandeling teenoor God, iemand wat nie meer geduldig is om te wag dat die Here uitkoms bring nie. 'n Mens het hier te doen met iemand wat self die loop van sake wil beheer $(6: 33)$. 
Die botsing tussen die koning en Elisa wat in vers 31 gesuggereer word, dui op 'n botsing van wilsbesluite: die wil van God (soos Elisa dit sien) en die wil van die koning (soos vergestalt in die adjudant). Die adjudant is sinies oor die profesie van uitkoms wat Elisa gee. Hiermee word die almag van Jahwe op die spel geplaas, omdat die adjudant die vermoë van God bevraagteken om binne vier-en-twintig uur uitkoms te gee. Hy dink egter in terme van natuurverskynsels, naamlik reën (7:2). Hy meen dat Jahwe alleen langs die gewone weë van die natuur kan voorsien. God moet volgens hom op dieselfde wyse as Baäl werk. Die verwysing na die Baälkultus kom na vore in die adjudant se verwysing na vensters in die hemel. Dit is 'n bevraagtekening wat mens ook in Ugaritiese tekste kry (vgl. teks 51, reëls 123-127 in Gordon, 1965:172):

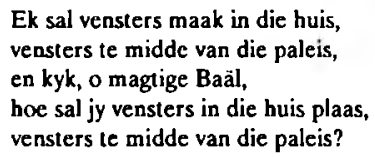

Die Kanaänitiese godsdiens het aan verskeie gode sekere posisies ten opsigte van die natuurkragte toegeken. Baäl was in beheer van die reën. Wanneer Baäl lewe, dan reën dit, maar as hy deur Mot oorwin word, dan is daar droogte. Die funksie van die venster van Baäl se huis is om reën na die aarde deur te laat. Die adjudant dink aan God in terme van Baäl. In sy woorde is daar 'n sinspeling op Jahwe se beperkte vermoë, asof hy ook deur een of ander god oorwin is soos wat Baäl deur Mot oorwin word. Hy twyfel dus aan Jahwe se krag.

Op hierdie wyse maak die adjudant 'n bespotting van Elisa en die God wat hy navolg; daarom word hy ter dood veroordeel. 'n Vroeëre bespotting van Elisa deur kinders het ook hulle dood tot gevolg gehad (2 Kon. 2:23-25). Die koning sien Elisa as 'n mens. Hy praat van hom as Elisa, die seun van Safat. As koning is hy self beskikker oor mense se lewe en lot, daarom wil hy Elisa as mens uit die weg ruim. Die lig waarin Elisa teenoor die adjudant gestel word, is egter anders. Teenoor hom tree Elisa bewustelik op as man van God $(2$ Kon. $7: 2,19)$ wanneer hy profeteer. Daarom ook is sy profesie gesaghebbend. Wanneer die adjudant sinies daarop reageer, kom dit neer op minagting vir Jahwe. Dit maak die profesie van sy dood as vervloeking soveel meer geloofwaardig. Dit herinner die lesers aan die seëninge en vervloekings van Deuteronomium 28:15 e.v..

\subsection{Die perspektief op die melaatses en die Arameërs in die laer}

Die verteller maak gebruik van drie sekondêre woordvoerders om die gebeure wat tot die ontdekking van die vlug van die Aramese leếr gelei het, die vlug self en die gebeure daarna, te beskryf. Die leser neem kennis van die melaatses se onderlinge konferensie 
en dilemma warin hulle verkeer (7:3). Ook word kennis geneem van die melaatses se skuldgevoel (7:9). Vers 6 en 7 is nie vanuit die perspektief van die melaatses beskryf nie, want hulle kon nie fisies teenwoordig gewees het toe die groot en vreesaanjaende geluide gehoor is nie. Die verteller mak hier gebruik van iemand in die laer om te beskrywe wat gebeur het. Deur die boodskappers ook as woordvoerders te gebruik, word die haas waarmee die leër gevlug het, bevestig. 'n Vergelyking tussen die fokalisasies op die melaatses, op die laer self en die boodskappers van die koning, lewer 'n interessante waarneming op:

\section{ARAMESE LAER}

6. Die Here laat die Arameërs 'n geluid van strydwacns, perde en 'n groot leêr hoor. Hulle dink dit is die koning van Israel wat die konings van Egipte en die Hetictc huur om Aram aan te val.

7. Hulle slaan op vlug. Hulle los dic hele kamp net soos dit is: tente, perde, donkies. Hulle vlug vir hulle lewe.

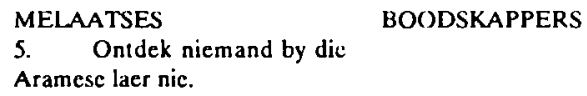

BOODSKAPPERS

8. Hulle gaan twee maal in dic tente in om te ect en te drink. Hulle neem silwer, goud 15. Vind die hele pad tot by die Jurdaan besaai met klere. en klere cn begrawe dit.

9. Dit is 'n dag van blydskap en hulle kan nic stilbly nie.

10. Hulle rapporteer aan die poortwagte dic volgende: daar was nicmand te sien of te hoor nie. Daar was net vasgemaakte donkies en perde. Die leër het die tente net so gelos.

.

Die vertelling van die gebeure in die laer van die Arameërs dui nie op 'n perspektief wat die leër goedgesind is nie. Hulle optrede word negatief beoordeel deurdat die verteller sê dat hulle bang was en vir hulle lewe gevlug het. Dit wat die melaatses gesien het en dit wat hulle rapporteer, verskil ook. Vers 8 maak geen melding van die diere nie, maar net van die buit. Die melaatses se berig aan die poortwagte in vers 10 makk weer geen melding van die buit nie, maar wel van die diere wat hulle vasgemaak gevind het. Die melaatses lê baie klem op die verlatenheid van die laer. Hulle swye oor die buit laat 'n mens wonder oor hulle motiewe. Die leser sal geneig wees om die melaatses simpatiek te benader: as uitgeworpenes verrig hulle 'n edele taak deurdat hulle boodskappers van goeie nuus oor die verlossing word. Ofskoon hulle verswyging van die buit 'n negatiewe lig op hulle werp, voel mens wel om hulle hulle buit te gun. Kry hulle nie swaar genoeg as uitgeworpenes van die samelewing nie? Die boodskap- 
pers wat na die melaatses uitgaan, se waarneming konsentreer op die wyse van vlug van die Arameërs en nie die toestand van die laer nie. Hulle waarneming benadruk die haas waarmee die leër moes padgegee het, omdat die lesers hoor van klere en voorwerpe wat al met die pad langs rondgestrooi is.

Die verteller dig die gebeure wat daartoe gelei het dat die beleg beëindig is, regstreeks aan Jahwe toe. Dit is 'n perspektief wat nòg deur die melaatses, nòg deur die poortwagters, nòg deur die boodskappers, nòg deur die koning gedeel word. Inteendeel, die perspektief wat die verteller aanbied, staan in skrille kontras met die koning se wantroue $(7: 12)$. Hy is van mening dat dit maar net 'n slinkse plan van die Arameërs was om die inwoners uit die stad uit te kry met die doel om hulle te vernietig. Ofskoon die melaatses die betekenis besef van wat hulle waargeneem het, is hulle eerste reaksie nie om aan God te dink nie, maar om soveel moontlik vir hulleself te verkry.

In die laaste deel van die verhaal, 7:16-20, bevestig die verteller as't ware sy "buiteperspektief" op die gebeure. Hy sê dat die profesie van Elisa uiteindelik bewaarheid is. Hy lê klem daarop dat dit gebeur het volgens die woord van Jahwe wat deur sy profeet gespreek is. Net dit wat met die dood van die adjudant gepaardgaan, word gegee. Daar word byvoorbeeld melding gemaak dat die adjudant oor die poort aangestel is (om hom in die poort te kry vir die vervulling van die profesie) en dat hy daar doodgetrap is deur die volk. Die verteller kom aan die einde van sy vertelling self tot 'n gevolgtrekking daaroor, naamlik dat die gebeurlikhede plaasgevind het soos wat dit deur die profeet voorspel is. Hierdie kommentaar verraai die verteller se ideologiese perspektief.

\subsection{Die ideologiese perspektief van die verteller}

Die kommentaar op die hele verhaal aan die einde van die vertelling in 7:16-20 bied ' $n$ perseptuele perspektief aan die lesers. Hiermee word bedoel die perspektief waardeur die gebeure van die verhaal aangebied is deur die verteller. Die verteller sien die gebeure in terme van dit wat Jahwe doen: $\mathrm{Hy}$ is die een wat in beheer van die geskiedenis staan en die dinge laat gebeur soos Hy dit wil laat gebeur. Hierdie perspektief kom veral in vier gebeure tot uitdrukking:

- Die beleg deur Aram: dit word as onheil gesien wat van die Here kom (6:33).

- Die profetiese woord van die Here: Jahwe sal toesien dat die gevolge van die hongersnood verlig word (7:1).

* 'n Tweede profetiese woord: diegene wat nie glo dat Hy by magte is om verlossing te bewerk nie, sal op die harde manier leer dat Jahwe aan die werk is (7:2).

* Die vlug van die Aramese leër: hulle vlug word regstreeks toegeskryf aan faktore wat Jahwe as Adonai bewerkstellig het (7:6). 
Konseptueel skaar die verteller hom by die perspektief uit die kring van Elisa wat die houding van die koning en sy vertroueling afkeur. Met konseptuele perspektief word bedoel die gesigspunt wat houdings en wêreldbeskouings weerspieël (cf Berlin 1983:47). Die egtheid van die koning se berou en medelye deur die dra van 'n roukleed word deur die kontras van sy verhouding met Elisa as man van God bevraagteken. Die lesers vra hulle af waaroor die koning nou eintlik berou het as hy wantrouig en ongeduldig staan teenoor Goddelike optrede. Waarom sien hy die optrede van Jahwe alleen as onheil, terwyl ook sy adjudant, wat sy vertroueling is, nie bereid is om iets goeds uit die hand van Jahwe te verwag nie?

Die ideologiese perspektief van die verhaal oor die beleg en verlossing van Samaria kan soos volg gedefinieer word:

Jahwe bring wel onheil oor die volk Israel, maar hulle word nie alleen gelaat nie. Deur die profetiese woord word die volk verseker van verlossing wat sal kom. Die volk het die verpligting om die profetiese woord te glo.

Die objek waarop hierdie perspektief hom rig, is die hongersnood wat tiperend was van 'n geloofsnood in Israel. Die gebrek aan geloof word gesien in die gevolge wat die hongersnood op die mense gehad het:

* kannibalisme van die vrouens;

- gierigheid en selfsug van die melaatses; en

- wantroue van die koning en sy adjudant teenoor Jahwe.

Die hongersnood word opgelos: die inwoners van Samaria kry genoeg om te eet. Die geloofsnood word nie opgelos nie: die adjudant sterf sonder dat die lesers weet of hy erken het dat daar verlossing uit die hand van God gekom het, hoewel hy dit moes gesien het. Of die koning wantrouig gebly het, weet die lesers nog minder.

In 2 Konings 6:24-7:20 het die lesers te doen met 'n verhaal waar die verteller die gebeure vanuit verskillende hoeke beskryf. Hierdie verskillende hoeke word tot 'n cenheid saamgevoeg in een samehangende perspektief. Van Aarde (1982:63) praat van die simplekse aard van 'n vertelling. Dit is wanneer die ideologiese perspektief saamval met die perspektief van die protagonis van die verhaal. So 'n saamval van perspektiewe gee voor dat al die gebeure vanuit een oorheersende perspektief aangebied word. Die verteller neem die hoofkarakter se perspektief aan en beoordeel die gebeure van die verhaal daaruit. In hierdie gedeelte identifiseer die verteller hom met die perspektief van Elisa, wat die aankondiger van die heilstyd vir die oorblyfsel van die volk is. Die koning en die adjudant kan nie verby die onheil waarin hulle hulleself bevind kyk nie en hulle neem Elisa kwalik. Die melaatses wat die heil eerstehands ervaar, misken die goddelike hand daarin. 


\section{DIE WAARDE VAN'n ANALISE VAN VERTELLERSPERSPEKTIEF}

Hoewel die vertelling melding maak van Goddelike optrede $(6: 33 ; 7: 6,16-18)$, bly dit in die analise van die stuk in die agtergrond. Wat belangriker is, is die optrede van mense. Elkeen se swakheid word uitgewys, byvoorbeeld die vrou se drang om ten alle koste te wil oorleef, die koning se woede en hulpeloosheid, die adjudant se sinisme en die melaatses se gierigheid. Hierdie swakhede is wesenskenmerke van die "in-sondevervalle-mens".

Die fokus op die menslike aspek maak dat die verhaal realisties oorvertel word. Die verhaal gaan oor mense van vlees en bloed wat handelend optree, met mekaar kragte meet en die slagoffers van hulle eie swakhede is. Hulle word op so 'n lewendige wyse uitgebeeld dat die leser homself daarin kan herken. Die gebeure word so lewensgetrou en aanskoulik voorgestel en aangebied dat die leser voel hy is 'n ooggetuie van die gebeure.

Deur te kyk na die rol van die verteller in die verhaal, het die didaktiese rol van die verteller na vore gekom. Die verteller het nie die lesers bekend gestel met al die gebeure met betrekking tot die beleg nie. Alleen enkele episodes is uitgelig en skerp in fokus gebring. Die karakters, in wie die lesers hulleself herken, is meesal anoniem. Hulle hoef ook nie na spesifieke mense in die verhaal te verwys nie, want hulle doel is om sekere waardes voor te stel. Die koning en die adjudant is die simbool van diegene wat nie meer op God vertrou nie en self oplossings vir hulle vervalle toestand soek. Elisa simboliseer diegene wat hulle vertroue weer op God vestig en op Hom wag vir'n oplossing in hulle doodstoestand. Dit wat met die adjudant gebeur, is eweneens sprekend van wat gebeur met mense wat nie in die profetiese woord glo nie. Die verkryging van voedsel is weer sprekend van diegene wat nie sinies staan teenoor die almag van God nie. Die stadspoort is vir dié wat glo 'n poort na die lewe, maar vir die sinikus is dit 'n poort na die dood.

Met behulp van die verteller word die lesers in die wêreld van die teks getrek. Die lesers word deelnemers aan die verhaal in dié mate wat hulle hulle met die karakters identifiseer of van die karakters distansieer. Die teks van die vertelling is nie bloot lettertekens wat gelees word om betekenis daarin te vind nie. Die lees van die teks is 'n spel waaraan die lesers deelneem ten einde in hulle eie gedagtes die vertelling weer te vertel soos hulle dit verstaan op grond van die aanduidings wat hulle dink die verteller gegee het om die verhaal te verstaan. In plaas daarvan om alleen op die gebeure waarna die teks verwys, te fokus, val die klem by die vertellersperspektiefanalise op die funksie van die vertelling en die effek op die lesers. Hiermee word aandag gegee aan die estetiese aspek van vertellings, deurdat die lesers se deelname aan die generering van betekenis uitgespel word. 


\section{WERKE GERAADPLEEG}

BAL, M. 1985. De theoric van vertellen en verhalen: Inleiding in de narratologie. Derde druk. Muiderberg : Dick Coutinho.

BERLIN, A. 1983. Poetics and interpretation of biblical narrative. Sheffield : The Almond Press.

COETZEE, J.C. 1979. 'n "Ou Bock in 'n nuwc wêrcld, of 'n nuwc Bock in 'n ou wèreld?". In die Skriflig, $13(49): 4-15$.

COETZEE, J.C. 1984. Die Skrif en wetenskap: hermeneutiese reèls. Welenskap en Woord. Potchefstroomse Studies vir Christelike Wetenskap, 5-32.

COETZEE, P.J. 1979. Die Teologiese Skool 'n kosbare pand. Goue Kandelaar, 18:6-7.

DEIST, F.E. 1986. Verteltekste. (In Deist, F.E. \& Vorster, W.S. reds. Woorde wat ver kom. Dic literatuur van dic Ou Testament. Deel I. Kaapstad : Tafelberg. p. 69-102)

EICHRODT, W. 1983. Theology of the Old Testament. Vol 1. London: SCM Press.

FLOOR, L. 1970. Calvyn se hermeneutick in vergelyking met Ebeling en Fuchs. Neotestamentica, 4:94 107.

FLOOR, L. 1980. Dic hermenculick van Calvyn. In die Skriflig, 14(55):13-20.

GADAMER, H. 1986. Wahrheit und Methode: Grundzüge einer philosophischen Hermencutik. Tübingen : JCB Mohr.

GENETTE, G. 1980. Narrative discourse. Oxford : Basil Blackwell.

GENETTE, G. 1988. Narrative discourse revisited. New York : Cornell University Press.

GORDON, C.H. 1\%65. Ugaritic texibook: (irammar, Iext in transliteration, cunciform seleclions, glossary indices. Rome: Puntifical Biblical Instilute.

GRAY, J. 1970. I and II Kings: a commentary. SCM Press: London.

GRäBE, 1. 1986a. Narralologiese ondersock en eksegese van die boodskap van die evangelies. Henomate Teologiese Studies, 42(1): 151-168.

GRaBE, 1. 1986b. Die gclykenis van die barmharlige Samaritaan: Narratiewe legnicke en vergelykingsformules. Henomide Teologiese Sindies, 42(2):265-281.

(iRiBE, I. 1990. Theory of literature and Old Testament studies: narrative conventions as exegetic reading strategies. Old Testament Essays, 3(1):43-59.

(GREIJDANUS, J. 1946. Schriftbeginsclen Ier Schriflverklaren. Kampen : Kok.

HELBERG, J.L. 1983. Verklaring en prediking van dic Ou Testament. Potchefstroom : Potchefstroomse Teologiese Studies.

JAUB, H. 1987. The book of Jonah: A paradigm of the "hermencutics of strangeness". Minneapolis : Universily of Minnesola.

KRAUS, H.J. 1977. Calvin's exegetical principles. Interpretation, 31:8-18.

KU(iEL, J. 1981. On the Bible and literary crilicism. Proseftexts, 1:217-236.

LICHT, J. 1978. Storyclling in the Bible. Jerusalem : Magnes Press. Hebrew University Jerusalem.

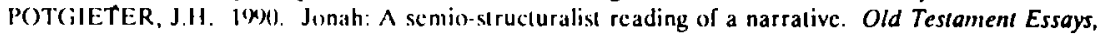
$3(1):(61-6)$.

RHOADS, D. \& MICHIE, M. 1982. Mark as story. Philadelphia : Fortress Press.

RIMMON-KENAN, S. 1983. Narrative fiction: contemporary poeties. London : Methuen.

SCHULZE, L.F. 1988. Strukturalisme en eksegese. NGTT, 29:139-153.

SMITS, L. 1957. Saint Augustin dans l'oeuvre de Jean Calvin. Assen: Van Gorcum.

VAN AARDE, A.G. 1982. Die vertellersperspekticf-analise. 'n Literatuurteoretiese benadering in dic ekscgese van die Evangelies. Henomude Trologiese Studies, 39(4):58-82.

VON RAD, G. 1982. Old Testament Theology. Vol II. London: SCM Press.

VORSTER, W.S. 1977. 'n Ou Bock in 'n nuwe wèreld - gedagtes rondom die interpretasic van die Nuwe Testament. Preloria : Unisa.

WUNBERG, G. 1983. Wicdercrkenncn, Literatur und ästhetisches Wahrnemung in der Moderne. Tubingen : Gunther Narr Verlag. 
